\title{
Are peripherally inserted central catheters in critical ill patients justified?
}

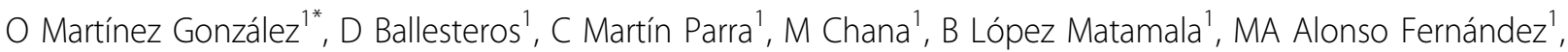 \\ B Estébanez ${ }^{2}$ J Luján ${ }^{3}$, R Blancas ${ }^{1}$
}

From ESICM LIVES 2015

Berlin, Germany. 3-7 October 2015

\section{Introduction}

Peripherally inserted central catheters are an alternative to central venous catheters in critically ill patients. In recent years its use is increasing despite first central access choice in these patients are central venous catheters.

\section{Objectives}

To describe if peripherally inserted central catheters are justified to be cannulated instead central venous catheters. Secondary objective is to describe the duration and time of cannulation related to admission time to the ICU.

\section{Methods}

A retrospective study conducted in the ICU of the Hospital Universitario del Tajo from 2008 to 2014. All peripherally inserted central catheters were collected, date of cannulation and removal, and the presence at the cannulation time of antiplatelet therapy, anticoagulation therapy (INR > 1.4), coagulopathy (INR > 1.4, prothrombin $\mathrm{T}+$ time $(\mathrm{PT})>60 \mathrm{sec}$, partial thromboplastin time $(\mathrm{PTT})>$ $45 \mathrm{sec})$, thrombocytopenia $\left(<100000 / \mathrm{mm}^{3}\right)$, anatomical alterations contraindicating central venous catheters cannulation, decubitus intolerance and/or obesity (BMI> 35). For the statistical analysis SPSS v.20.0 software was used, using percentages to describe quantitative variables and means, or medians, to describe quantitative variables.

\section{Results}

204 peripherally inserted central catheters were cannulated. The median duration was 3 days (CI 25\% -75\%: $2-4$ ). Only 108 catheters, 58.9\% (95\% CI:46,3\%-60,1\%),

${ }^{1}$ Hospital Universitario del Tajo, Critical Care, Aranjuez, Spain

Full list of author information is available at the end of the article had justification for cannulation instead of central venous catheters. The most frequent causes were coagulopathy in 47 patients $(23.0 \%)$ and antiplatelet therapy in $33(16.2 \%)$ (Table 1$)$. Most of the peripherally inserted central catheters cannulated were at the afternoon shift (15:00-22:00) being this setting 91 catheters, $37.9 \%$ (95\% CI: 44,2\%-51,2\%).

\section{Conclusions}

Cannulation peripheral inserted central catheters requires further justification now at ICU. Pending further studies, central venous catheters is now the first central access choice in critically ill patient, so peripheral inserted central catheters is an alternative in selected patients with risk factors to increase incidence of complications.

\section{Authors' details}

${ }^{1}$ Hospital Universitario del Tajo, Critical Care, Aranjuez, Spain. ${ }^{2}$ Hospital Universitario la Paz, Critical Care, Madrid, Spain. ${ }^{3}$ Hospital Universitario

Príncipe de Asturias, Critical Care, Alcalá de Henares, Spain.

Table 1

\begin{tabular}{|c|c|c|c|c|}
\hline & $\begin{array}{l}\text { Number } \\
\text { of } \\
\text { patients }\end{array}$ & Percentage & $\begin{array}{l}\text { Lower } \\
\text { limit } \\
\text { (Cl 95\%) }\end{array}$ & $\begin{array}{l}\text { Upper } \\
\text { Limit } \\
\text { (CI 95\%) }\end{array}$ \\
\hline Obesity(BMl>35) & 19 & 9,3 & 6 & 14,1 \\
\hline $\begin{array}{l}\text { Antiplatelet } \\
\text { therapy }\end{array}$ & 33 & 16,2 & 11,8 & 21,8 \\
\hline $\begin{array}{l}\text { Anticoagulation } \\
\text { Therapy }\end{array}$ & 30 & 14,7 & 10,5 & 20,2 \\
\hline Coagulopathy & 47 & 23 & 17,8 & 29,3 \\
\hline Thrombocytopenia & 6 & 2,9 & 1,3 & 6,3 \\
\hline $\begin{array}{l}\text { Anatomical } \\
\text { Alterations }\end{array}$ & 1 & 0,5 & 0 & 2,7 \\
\hline $\begin{array}{l}\text { Decubitus } \\
\text { intolerance }\end{array}$ & 23 & 11,3 & 7,6 & 16,3 \\
\hline
\end{tabular}

(c) 2015 Martínez González et al.; This is an Open Access article distributed under the terms of the Creative Commons Attribution License (http://creativecommons.org/licenses/by/4.0), which permits unrestricted use, distribution, and reproduction in any medium, provided the original work is properly cited. 
doi:10.1186/2197-425X-3-S1-A72

Cite this article as: Martínez González et al:: Are peripherally inserted central catheters in critical ill patients justified? Intensive Care Medicine Experimental 2015 3(Suppl 1):A72.

Submit your manuscript to a SpringerOpen ${ }^{\mathcal{O}}$ journal and benefit from:

- Convenient online submission

- Rigorous peer review

- Immediate publication on acceptance

- Open access: articles freely available online

- High visibility within the field

- Retaining the copyright to your article

Submit your next manuscript at $\gg$ springeropen.com 